\title{
The Influence of Principal Supervision on Organizational Commitment, and Emotional Intelligence on Work Discipline, Work Motivation and Performance of State High School Teachers in North Maluku Province
}

\author{
Faripa La Hitu ${ }^{1}$, Amiartuti Kusumaningtyas ${ }^{1}$, I Dewa Ketut Raka Ardiana ${ }^{1}$ \\ ${ }^{1}$ Universitas 17 Agustus 1945 Surabaya, Indonesia
}

Received: January 8, 2021

Revised: February 6, 2022

Accepted: February 12, 2022

\begin{abstract}
The purpose of this research is to ascertain the direct effect of principal supervision, organizational commitment, and emotional intelligence on the work discipline, motivation, and performance of state high school teachers in five districts in North Maluku. The populations studied in this research included all State Civil Apparatus instructors who had worked for at least five years, which totaled 515 individuals. A proportionate random sampling technique is then used to distribute the 225 samples throughout the districts and cities. However, only 186 questions were gathered since a natural catastrophe struck one of the study sites during the time the questionnaire was being collected, preventing the researcher from collecting the whole questionnaire. The validity and reliability tests were conducted in this research using SEM (AMOS.24). The findings of this study indicate that: (1) principal Supervisionon has no significant effect on work discipline; (2) organizational commitment has a significant effect on work discipline; (3) emotional intelligence has a significant effect on work discipline; (4) principal Supervisionon has no significant effect on work motivation; (5) organizational commitment has no significant effect on work motivation; and (6) there is a significant effect of emotional intelligence on work discipline.
\end{abstract}

Keywords: Principal Supervision, Organizational Commitment, Emotional Intelligence, Work Discipline, Work Motivation, Teacher Performance

\section{Introduction}

Education in schools is not only a process of imparting information; it also encompasses a variety of physical, emotional, and economical components. Education must represent authentic programming and meet the diverse demands of educational service consumers. Education must also be capable of developing the environment and comprehending many aspects of the environmental system's components. Individuals are highly influenced by their surroundings, which has a variety of ramifications for the learning and education setting.

Teachers as educators must have a psychological understanding of the factors that influence students and how they develop in various educational environments; consequently, teachers as educators must also pay close attention to the classroom environment, which has a significant impact on the teaching and learning process.

Teacher performance will improve if teachers get enough supervision from superiors. Supervision by those who are experts/professionals in their professions has the potential to boost an individual's performance (Taylor, 2015; Engkoswara \& Komariah, 2011).

Additionally, a person's dedication to the organization for which he works is necessary. Organizational commitment refers to the nature of the relationship between individuals and work organizations in which individuals believe in the work organization's values and goals, are willing to use their business seriously for the benefit of the work organization, and have a

Copyright $@$ 2022, Journal of Asian Multicultural Research for Economy and Management Study, Under the license CC BY-SA 4.0 
strong desire to remain a part of the work organization. Individuals identify with a specific organization in which they work and want to become members in order to contribute to the accomplishment of the organization's aims (Luthans, 2011).

Emotional intelligence is also needed when someone is in an organization. Emotional intelligence is a person's ability to recognize oneself and others, including the ability to manage one's own emotions in relation to others (Dhani \& Sharma, 2016; Goleman, 2005). Someone who has good Supervisionon, has a commitment to the organization and has good emotional intelligence will cause a person to have a high sense of discipline at work. Besides that, someone will also be motivated to work.

Discipline is a person's awareness and willingness to obey all regulations and norms that apply in an organization. Awareness is the attitude of a person voluntarily obeying existing regulations and being self-aware of the tasks and responsibilities given. Willingness is an attitude and behavior as well as a person's actions in accordance with the regulations set by the organization, both written and unwritten (Zelenika et al., 2018; Hasibuan, 2014). With high work discipline supported by self-awareness and willingness to carry out work activities well as a member of the organization, it will produce good work motivation.

Work motivation will increase well if it is supported by the motivation of the individual himself. Factors that encourage a person to carry out activities are certainly driven by the needs and desires of the individual. With the need and strong desire of the individual will encourage the individual to perform a work activity well, with good work activities will produce good performance as well. Thus, high work motivation will improve performance well. Work motivation is a complex combination of psychological forces within each person (Wibowo, 2017).

Someone with high work discipline and strong work motivation can be predicted to have good performance as well. A person's performance can be said to be good if someone has talent and a good role in the organization. Performance is the result of work that has been achieved by a person or group in an organization achieved within a certain period (Hariandja \& Effendi, 2005). The work that has been achieved by someone in an organization can be said as individual performance. Individual performance will be good if it is driven by a strong desire. With a strong desire, it will produce good results and with good results, the individual's performance can also be said to be good.

Education in North Maluku Province in recent years is quite alarming. Based on data from the Central Statistics Agency (BPS) from 34 provinces, North Maluku's position is always at number 31 in the Human Development Index (IPM). Some of the main indicators of the decline in education in North Maluku are: 1) poor education governance for creating a conducive environment for the development of education. This can be observed from the education management institutions, human resources, and education funding that have not shown policies that are professional, transparent, and pro to the quality of education; 2) the derivative implication of governance weaknesses is poor education administration with frequent delays in the disbursement of School Operational Assistance (BOS) funds so that it has a major influence on the implementation of the teaching and learning process. Psychologically, it is very disturbing for education implementers (teachers, students, and school officials) in improving the quality of education in accordance with the expected performance targets; 3 ) The political will of the government has not wholeheartedly placed education as an investment in the process of accelerating development (Suisworo, 2018).

Based on this description, the problem in this study is the teacher's perceived performance is less than optimal. This is due to a lack of discipline in work and strong motivation at work. 
Undisciplined at work and weak motivation at work are caused by lack of Supervisionon from the principal, lack of teacher commitment to the organization, and low levels of teacher emotional intelligence.

\section{Literature Review}

\section{Supervisionon}

Mulyasa (2013) Supervisionon etymologically comes from the words super and vision which means to see and review from above or view and assess from above what is done by the superior on the activities, creativity and performance of subordinates. Engkoswara \& Komariah (2011), Supervisionon can mean Supervisionon carried out by people who are experts/professionals in their fields so that they can provide improvements and enhancements/guidance so that learning can be carried out well and of high quality. Purwanto (2009) explains that Supervisionon is a coaching activity that is planned to assist teachers and other school employees in doing their jobs effectively. Supervisionon of school principals in the Regulation of the Minister of National Education number 13 of 2007, concerning Standards for Principals/Madrasah, emphasizes that a principal/madrasah must have five competencies, namely personality, managerial, entrepreneurial, supervisory, and social competencies. One of the principal competencies is academic Supervisionon which includes three aspects, namely:

Planning an academic Supervisionon program in the context of increasing teacher professionalism, with positions; Carry out academic Supervisionon of teachers with appropriate Supervisionon approaches and techniques; Follow up on the results of academic Supervisionon of teachers in order to increase teacher professionalism.

\section{Organizational Commitment}

In an organization, to achieve goals and achieve success, quality human resources and have good competence are needed to run the organization in order to achieve the goals that have been set. In order to achieve organizational goals, it takes commitment from members of the organization. Commitment is basically a person's willingness to bind themselves and show loyalty to the organization because they feel they are involved in organizational activities (Wibowo, 2017). Mathis \& John (2001) provide a definition of organizational commitment is the level of trust and acceptance of employees towards organizational goals and have a desire to remain in the organization. Commitment to the organization means more than formal membership, because it includes an attitude of liking the organization and a willingness to put forth a high level of effort for the benefit of the organization in order to achieve goals. Luthans (2011) suggests the dimensions of commitment according to Allen and Meyer (1993) which are identified in three components, namely:

Affective commitment is a feeling of love for an organization that creates a willingness to stay and build social relationships and appreciate the value of relationships with the organization because they have become members of the organization.

Continuance commitment is a heavy feeling to leave the organization because of the need to survive with consideration of the costs of leaving the organization and the rewards associated with participation in the organization. Normative commitment is a feeling that requires to stay in the organization due to obligations and responsibilities to the organization based on considerations of employee norms, values and beliefs.

\section{Emotional Intelligence}

Emotional intelligence is two products and two main skills, namely self-awareness skills and self-management skills which are included in personal competence and the second is social

Copyright $@$ 2022, Journal of Asian Multicultural Research for Economy and Management Study, 
awareness skills and social relationship management skills which are included in social competence. Personal competence is more focused on oneself as an individual, while social competence is more focused on a relationship to others (Bradberry \& Greaver, 2007). Goleman (2005) reveals that emotional intelligence refers to the ability to recognize our own feelings and the feelings of others, the ability to motivate ourselves, and the ability to manage emotions well in ourselves and in relationships with others. Goleman (2005) states that the basic emotional and social skills include the following elements: (1) Self-awareness, (2) Selfregulation, (3) Motivation, Empathy, means feeling as others feel, being able to understand their perspective fostering trusting relationships and aligning oneself with various people. (4) Social skills.

\section{Work Discipline}

The success of various activities within the organization in achieving organizational goals does not only depend on the superiority of technology and operational funds provided by the facilities and infrastructure owned, but all of these things depend on aspects of human resources. One very important example in HRM is discipline (Hasibuan, 2014). Sutrisno (2015) work discipline is a tool used by managers to communicate with employees so that they are willing to change a behavior as well as an effort to increase one's awareness and willingness to obey all company regulations and applicable social norms. Sutrisno (2015) work discipline is a tool used by managers to communicate with employees so that they are willing to change a behavior as well as an effort to increase one's awareness and willingness to obey all company regulations and applicable social norms.

\section{Work Motivation}

Work motivation is a stimulant of desire and a driving force of will that creates a person's enthusiasm to achieve a desired goal. Work motivation is the result of a collection of internal and external forces that cause workers to choose an appropriate course of action by using certain behaviors (Newstrom, 2011). Wibowo (2017), suggests that work motivation is the strength of a complex combination of psychological forces within each person. In other words, each individual has their own different motivations. Robbins (2003:208) defines work motivation as a process that produces an intensity, direction and individual persistence in an effort to achieve goals in his work. Wiles (1955), Bafadal (2004) that the high and low work motivation of teachers greatly affects their performance in completing their tasks. Another important concept of motivation based on the strengths that exist in humans is achievement motivation according to McClelland, a person is considered to have motivation if he has a desire to achieve better than others in many situations Mc. Clelland reinforces the three needs in Hasibuan (2014), namely: (1) The need for achievement (n Ach), is a driving force that motivates one's work spirit. (2) Need for affiliation (n Af). (3) The need for power (n Pow) is the driving force that motivates employee morale.

\section{Teacher Performance}

Helfert (1996) (Goal, 2014) argues that performance is a display of the complete state of the company over a certain period of time and is a result or achievement that is influenced by the company's operational activities in utilizing its resources. Wibowo (2014), Performance Assessment is a process of assessing how well workers have carried out their duties over a certain period of time. Darmadi (2018) teacher performance is the ability shown by the teacher in carrying out his duties or work. Performance is the result of work achieved by teachers in schools in order to achieve school goals or educational goals. Teacher performance can be seen from the teacher's responsibility in carrying out the mandate, the profession carried out, and the morals they have. This is reflected in his attitude of obedience, commitment, and 
loyalty in developing the potential of students and advancing the school. Teacher performance can be interpreted as a condition that shows the ability of a teacher in carrying out tasks at school describing the existence of a production that is displayed in or during learning activities (Kompri, 2015). Based on the understanding of experts, it can be concluded that teacher performance is the ability of teachers to apply the skills and behaviors they have and are responsible for students in carrying out their duties as educators.

$\mathrm{H} 7$

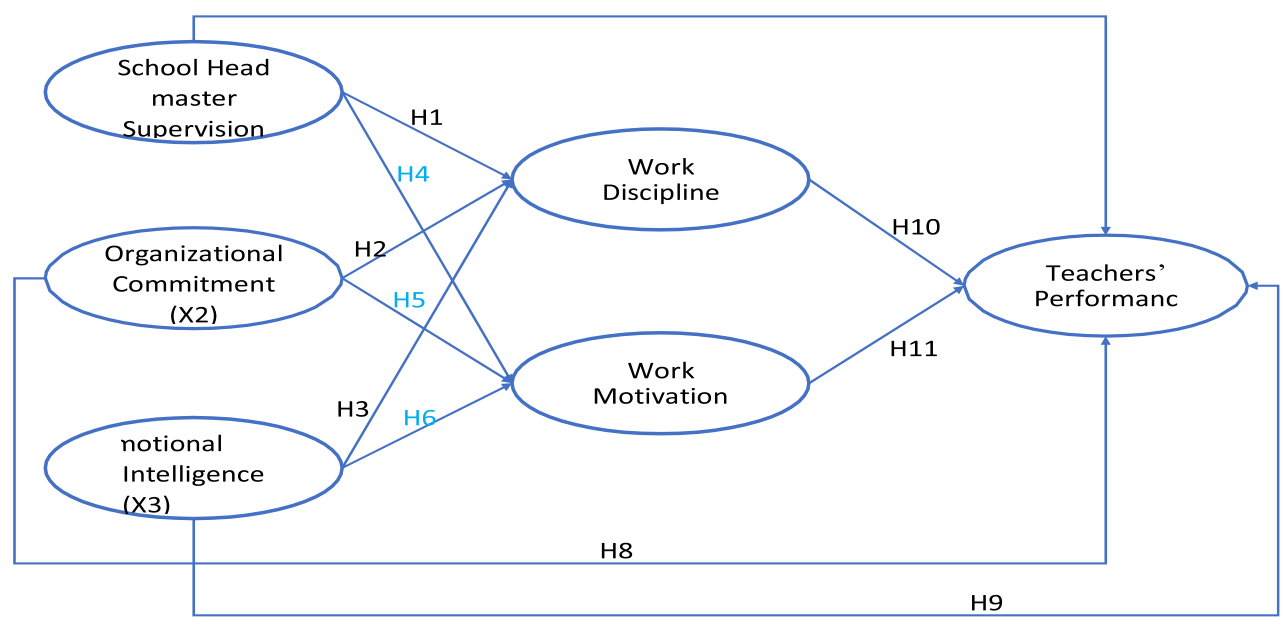

Figure 1. Conceptual Framework

\section{Methods}

This research is a quantitative research with survey method. Questionnaires are used as the main tool to collect data and are used as primary data. To support this research, researchers used literature studies and previous research, coupled with data collection in the field through questionnaires that were tested using validity and reliability tests and processed using SEM (Structural Equitem Modeling) data analysis. After the data is processed, it is discussed in the discussion of the data that has been processed and analyzed, then conclusions and suggestions are drawn from the discussion. The object of this research is a teacher with the status of a Civil Servant (PNS) who teaches at a State Senior High School in North Maluku Province. The population in this study were public high school teachers spread in five districts farthest from the capital city of North Maluku Province, status as Civil Servants (PNS) who had worked for a minimum of five (5) years totaling 515 people spread over 79 public high schools. The sampling technique used is probability sampling technique. Based on the sampling technique above, it can be determined the size of the sample in this study using the Slovin formula. The results of the calculation of the number of samples of 225 are then distributed to each city district by means of proportional random sampling.

\section{Results and Discussion}

The validity test was conducted to determine whether the questions in the questionnaire were representative enough. The validity test was carried out using confirmatory factor analysis on all latent variables, namely Supervisionon, Organizational Commitment, Emotional Intelligence, Discipline, Motivation and Teacher Performance with the help of the AMOS 24.0 program, as follows: 


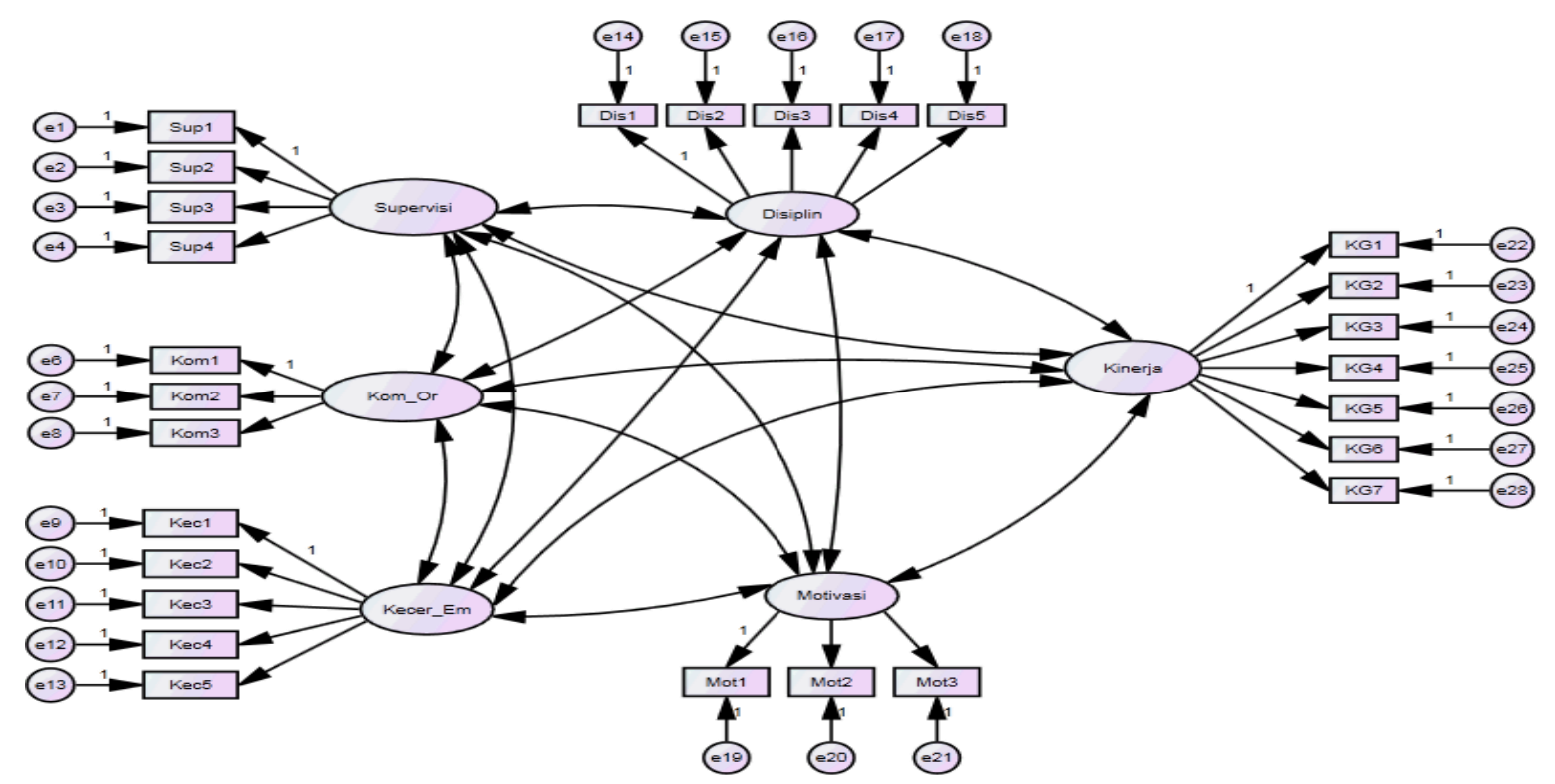

Figure 2. CFA Model - Beginning

\section{Hypothesis Proving}

The final structural equation model that has been tested and evaluated in the previous section, then the Amos 24.0 program provides the results of calculating the influence between variables as the basis for proving the hypothesis in this study.

Table 1. The Influence of Constructs on the Structural Equation Model

\begin{tabular}{|c|c|c|c|c|c|}
\hline Influence between Variables & $\begin{array}{c}\text { Standardize } \\
\text { d Weight }\end{array}$ & S.E & C.R. & $\mathbf{P}$ & Description \\
\hline Supervision => Work Discipline & 0,150 & 0,078 & 1,783 & 0,075 & Not Significant \\
\hline $\begin{array}{c}\text { OrganizationalCommitment => } \\
\text { Work Discipline }\end{array}$ & 0,242 & 0,084 & 2,738 & 0,006 & Significant \\
\hline $\begin{array}{c}\text { Emotional Intelligence => Work } \\
\text { Discipline }\end{array}$ & 0,244 & 0,080 & 2,841 & 0,004 & Significant \\
\hline $\begin{array}{c}\text { Supervision => Work } \\
\text { Motivation }\end{array}$ & 0,024 & 0,078 & 0,270 & 0,787 & Not Significant \\
\hline $\begin{array}{c}\text { OrganizationalCommitment => } \\
\text { Work Motivation }\end{array}$ & 0,175 & 0,082 & 1,903 & 0,057 & Not Significant \\
\hline $\begin{array}{c}\text { Emotional Intelligence => Work } \\
\text { Motivation }\end{array}$ & 0,276 & 0,083 & 2,886 & 0,004 & Significant \\
\hline $\begin{array}{c}\text { OrganizationalCommitment => } \\
\text { Teacher Performance }\end{array}$ & 0,098 & 0,102 & 1,194 & 0,232 & Not Significant \\
\hline $\begin{array}{c}\text { Emotional Intelligence => } \\
\text { Teacher Performance }\end{array}$ & 0,262 & 0,104 & 3,053 & 0,002 & Significant \\
\hline $\begin{array}{c}\text { Supervision => Teacher } \\
\text { Performance }\end{array}$ & 0,093 & 0,093 & 1,210 & 0,226 & Not Significant \\
\hline $\begin{array}{c}\text { Work Discipline } \\
\text { Teacher Performance }\end{array}$ & 0,165 & 0,108 & 1,987 & 0,047 & Significant \\
\hline $\begin{array}{c}\text { Work Motivation }=> \\
\text { Teacher Performance }\end{array}$ & 0,224 & 0,118 & 2,628 & 0,009 & Significant \\
\hline Work & Discipline & 0,182 & \\
\hline
\end{tabular}

Copyright $\odot$ 2022, Journal of Asian Multicultural Research for Economy and Management Study, Under the license CC BY-SA 4.0 


\begin{tabular}{|l|c|c|}
\hline R2 & $\begin{array}{c}\text { Work } \\
\text { Motivation }\end{array}$ & 0,124 \\
\cline { 2 - 3 } & $\begin{array}{c}\text { Teacher } \\
\text { Performance }\end{array}$ & 0,289 \\
\cline { 2 - 3 } & & \\
\hline
\end{tabular}

Principal supervision has a positive influence of 0.150 on Work Discipline. This effect is accompanied by a significance level (p) of 0.075 . In other words, H1 cannot be accepted and H0 cannot be rejected, which means that Supervision has a positive but not significant influence on changes in Work Discipline.

Organizational Commitment has a positive influence of 0.242 on Work Discipline. This effect is accompanied by a significance level (p) of 0.006. In other words, $\mathrm{H} 0$ is rejected and $\mathrm{H} 2$ is accepted, which means that Organizational Commitment has a positive and significant influence on changes in Work Discipline.

Emotional Intelligence has a positive influence of 0.244 on Work Discipline. This effect is accompanied by a significance level (p) of 0.006. In other words, H0 is rejected and H3 is accepted, which means that Emotional Intelligence has a positive and significant influence on changes in Work Discipline. Work Discipline has an R2 of 0.182, meaning that the Principal Supervision, Organizational Commitment and Emotional Intelligence contributed $18.2 \%$ to the Work Discipline amount. In other words, there are $81.8 \%$ of the work discipline that can still be influenced by other variables that are not included in the study.

Principal supervision has a positive influence of 0.024 on Work Motivation. This effect is accompanied by a significance level (p) of 0.787 . In other words, H4 cannot be accepted and H0 cannot be rejected, which means that Supervision has a positive but not significant influence on changes in Work Motivation. Organizational Commitment has a positive influence of 0.175 on Work Motivation. This effect is accompanied by a significance level (p) of 0.057 . In other words, $\mathrm{H} 5$ cannot be accepted and $\mathrm{H} 0$ cannot be rejected, which means that Organizational Commitment has a positive but not significant influence on changes in Work Motivation.

Emotional Intelligence has a positive influence of 0.276 on Work Motivation. This effect is accompanied by a significance level (p) of 0.004 . In other words, H0 is rejected and H6 is accepted, which means that Emotional Intelligence positively and significantly influences changes in Work Motivation. Work Motivation has an R2 of 0.124, meaning that the principal's Supervision, Organizational Commitment and Emotional Intelligence contribute $12.4 \%$ to the amount of Work Discipline. In other words, there are $87.6 \%$ of work motivation that can still be influenced by other variables that are not included in the study. Principal supervision has a positive influence of 0.093 on Teacher Performance. This effect is accompanied by a significance level (p) of 0.226 . In other words, H9 cannot be accepted and H0 cannot be rejected, which means that Supervision has a positive but not significant influence on changes in Teacher Performance.

Organizational Commitment has a positive influence of 0.098 on Teacher Performance. This effect is accompanied by a significance level (p) of 0.232. In other words, $\mathrm{H} 7$ cannot be accepted and $\mathrm{H} 0$ cannot be rejected, which means that Work Motivation has a positive but not significant influence on changes in Teacher Performance. Emotional Intelligence has a positive influence of 0.262 on Teacher Performance. This effect is accompanied by a significance level (p) of 0.002. In other words, $\mathrm{H} 0$ is rejected and $\mathrm{H} 8$ is accepted, which means that Emotional Intelligence has a positive and significant influence on changes in Performance. 
Work Discipline has a positive influence of 0.165 on Teacher Performance. This effect is accompanied by a significance level (p) of 0.047. In other words, H0 is rejected and H10 is accepted, which means that Work Discipline has a positive and significant influence on changes in performance. Work Motivation has a positive influence of 0.224 on Teacher Performance. This effect is accompanied by a significance level (p) of 0.009. In other words, $\mathrm{HO}$ is rejected and $\mathrm{H} 11$ is accepted, which means that Work Motivation is positive and significantly influences changes in performance.

Teacher Performance has an R2 of 0.289, meaning that the principal's Supervision, Organizational Commitment and Emotional Intelligence contribute, Work Discipline and Work Motivation of $28.1 \%$ in Teacher Performance. In other words, there are $72.9 .8 \%$ of the work discipline that can still be influenced by other variables that are not included in the study.

The findings in this study provide theoretical implications as well as practical implications. The theoretical implications generated in this study have been described above. Furthermore, the practical implications for Teacher Performance in five districts in North Maluku.

The results of this study found two hypotheses that were proven true, namely that there was a significant influence between Organizational Commitment and Emotional Intelligence on the Work Discipline of State Senior High School teachers in five districts in North Maluku. This shows that teachers in five districts in North. Maluku in improving discipline pay attention to indicators from Organizational Commitment as well as Emotional Intelligence and continuously use these indicators to improve their Work Discipline.

The results of this study found one hypothesis that was proven true, namely that there was a significant influence between Emotional Intelligence on the Work Motivation of State Senior High School teachers in five districts in North Maluku. This shows that teachers in five districts in North Maluku in increasing motivation pay attention to indicators of emotional intelligence to increase their motivation at work so that the work motivation of public high school teachers in five districts in North Maluku is very good. The results of this study found three hypotheses that were proven true, namely that there was a significant influence between Emotional Intelligence, Work Discipline and Work Motivation and Teacher Performance in SMA Negeri in five districts in North Maluku. This shows that in improving the performance of public high school teachers in five districts in North Maluku apply the indicators in Emotional Intelligence, Work Discipline and Work Motivation so that Teacher Performance becomes good.

The results of this study found one hypothesis that was not proven true, namely predicting the supervision of the principal has a significant effect on Work Discipline. However, the results showed that there was no significant effect between the principal's supervision and the work discipline. This shows that public high school teachers in five districts in North Maluku consider that the supervision carried out by the principal has not been able to improve Work Discipline, it is due to the lack of supervision because the principal always makes official trips to the capital city so that supervision does not run well. The results of this study found two hypotheses that were not proven true, namely predicting principal's supervision and organizational commitment to have a significant effect on work motivation. However, the results showed that there was no significant effect between principal supervision and organizational commitment to teacher work motivation in five districts in North Maluku. This shows that the supervision carried out by the school principal has not been able to improve teacher performance due to the lack of supervision by the principal, both educational supervision and academic supervision for teachers. 
Organizational Commitment owned by the teacher has not been too strongly implanted in himself as a member of the organization so that the existing commitment has not been able to motivate himself well at work. The results of this study also found two hypotheses that were not proven to be true, namely predicting that there was a significant influence between the Principal's Supervision and Organizational Commitment on Teacher Performance. However, the results of the study show that there is no significant effect between the supervision of school principals and organizational commitment to Teacher Performance in SMA Negeri in five districts in North Maluku. This shows that the principal's supervision and organizational commitment have not been able to have a major influence on improving Teacher Performance in five districts in North Maluku, this is due to the lack of supervision carried out by school principals which can trigger the decline in Teacher Performance due to a lack of commitment by the school principal. a teacher in carrying out his duties as a member of the organization.

\section{Conclusion}

Principal supervision has no significant influence on the Work Discipline of State Senior High School teachers in five districts in North Maluku. Organizational Commitment has a significant influence on Work Discipline of State Senior High School teachers in five districts in North Maluku. Emotional Intelligence has a significant influence on Work Discipline of State Senior High School teachers in five districts in North Maluku. Principal supervision has a significant influence on teacher work motivation in five districts in North Maluku. Organizational commitment has no significant influence on work motivation of state high school teachers in five districts in North Maluku. Emotional Intelligence has a significant influence on work motivation of state high school teachers in five districts in North Maluku. Principal supervision has no significant influence on Teacher Performance of State Senior High Schools in five districts in North Maluku. Organizational Commitment has no significant influence on Teacher Performance in State Senior High Schools in five districts in North Maluku. Emotional intelligence has a significant influence on Teacher Performance in five districts in North Maluku. Work Discipline has a significant influence on work performance of teachers in five districts in North Maluku. Work Motivation has a significant influence on Teacher Performance in State Senior High Schools in five districts in North Maluku. Brief conclusions from the results of this study are: there are 6 (six) hypotheses that are accepted as true and 5 (five) hypotheses are rejected.

\section{References}

Bafadal. (2004). Peningkatan Profesionalisme Guru SD. Jakarta: Bumi Aksara

Bradberry, T, \& Greaves, J. (2007). Menerapkan EQ di Tempat Kerja dan Ruang Keluarga. Yogyakarta: Think Jogjakarta.

Darmadi. (2018). Manajemen Sumber Daya Manusia Kekepalasekolahan "Melejitkan Produktivitas Kerja Kepala Sekolah dan Faktor-Faktor yang Memengaruhi”. Yogyakarta: Deepublish

Dhani, P., \& Sharma, T. (2016). Emotional intelligence; history, models and measures. International journal of science technology and management, 5(7), 189-201.

Engkoswara \& Komariah, A. (2011). Administrasi Pendidikan. Bandung: Alfabeta

Goal J. CHR. (2014). A to Z Human Capital. Jakarta: PT Grasindo Anggota Ikapi

Goleman, D. (2005). Emotional Intelligence, terj. T. Hermaya. Jakarta: Gramedia Pustaka Utama. cet. XIV. 
Hariandja M. T. \& Efendi, H. Yovita, (2002). Manajemen Sumber Daya Manusia: Pengadaan, pengembangan, pengkompensasian dan peningkatan produktivitas Pegawai. Bandung: Grasindo Widiasrana Indonesia.

Hasibuan, M. S.P. (2014). Manajemen Sumber Daya Manusia (Edisi Revisi). Jakarta: Bumi Aksara.

Kompri. (2015). Motivasi Pembelajaran: Prespektif Guru dan Siswa. Bandung: Rosd

Luthans. F. (2011). Organizational Behavior. New York: McGraw-Hill

Mathis, R. L. \& John H. J. (2001). Manajemen Sumber Daya Manusia: Buku 1. Jakarta: Salemba Empat

Mulyasa. H. E. (2013). Manajemen dan kepemimpinan Kepala Sekolah. Cetakan ke-3. Jakarta: PT. Bumi Aksara.

Newstrom, J. W. (2011). Organizational Behavior Human at Work. New York: McGraw-Hill

Purwanto. M. N. (2009). Administrasi dan Supervision Pendidikan. Cetakan Ke-19. Jakarta: PT. Remaja Rosdakarya

Republik Indonesia. Peraturan Menteri Pendidikan Nasional Nomor 13 Tahun 2007 Tentang Standar Kepala Sekolah/Madrasah.

Sutrisno. E. (2015). Manajemen Sumber Daya Manusia. Cet. Ke -7. Jakarta: Prenadamedia Group.

Taylor, B. M. (2015). The integrated dynamics of motivation and performance in the workplace. Performance Improvement, 54(5), 28-37.

Wibowo. (2014). Manajemen Kinerja. Edisi revisi cetakan -4. Jakarta: Rajawali Pers

Wibowo. (2017). Perilaku dalam Organisasi. Jakarta: RajaGrafindo Persada

Zelenika, I., Moreau, T., Lane, O., \& Zhao, J. (2018). Sustainability education in a botanical garden promotes environmental knowledge, attitudes and willingness to act. Environmental education research, 24(11), 1581-1596. 